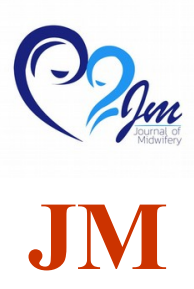

Volume 8 No. 1 (April 2020)

(C) The Author(s) 2020

\title{
PENGARUH PIJAT OKSITOSIN TERHADAP NYERI PERSALINAN PADA IBU BERSALIN DI RUMAH SAKIT PERMATA BUNDA PURWODADI GROBOGAN
}

\section{EFFECT OF MASSAGE OXYTOCIN ON MATERNITY PAIN IN CHILDBIRTH MOTHER IN THE HOSPITAL PERMATA BUNDA PURWODADI GROBOGAN}

\author{
LAILY HIMAWATI, NURUL KODIYAH \\ DOSEN STIKES AN NUR PURWODADI, \\ Email: laily.himawati05@gmail.com,nurulkodiyah20@gmail.com
}

\begin{abstract}
ABSTRAK
Latar Belakang: Persalinan adalah suatu proses fisiologis yang memungkinkan terjadinya serangkaian perubahan besar pada seorang ibu untuk dapat mengeluarkan janinnya melalui jalan lahir ibu. Setiap ibu hamil pasti mendambakan persalinan yang normal dan minimal akan rasa nyeri. Namun demikian, bagi seorang wanita khususnya ibu muda, proses persalinan seringkali merupakan sesuatu yang sangat menakutkan dan identik dengan rasa nyeri. Nyeri persalinan merupakan proses yang fisiologis. Apabila nyeri tidak diatasi dengan baik akan menimbulkan masalah yang lain diantaranya meningkatnya kecemasan atau rasa khawatir akan proses persalinan sehingga produksi hormon adrenalin meningkat dan mengakibatkan vasokonstriksi yang menyebabkan aliran darah ibu ke janin menurun. Janin akan mengalami hipoksia sedangkan ibu akan mengalami persalinan lama dan dapat juga meningkatkan tekanan sitolik dan distolik. Dikarenakan takut akan rasa nyeri persalinan, tak sedikit ibu hamil yang memilih seksio sesarea untuk persalinannya, karena mereka merasa dengan seksio sesarea proses persalinan akan lebih cepat dan jauh dari rasa nyeri.Nyeri persalinan merupakan hal yang sangat ditakuti oleh sebagian besar ibu hamil yang akan bersalin, terdapat banyak metode untuk mengurangi bahkan menghilangkan nyeri persalinan, salah satunya dengan menggunakan pijat oksitosin. Metode: Metode dalam penelitian ini adalah quasi eksperimental. Pengambilan sampel dilakukan secara accidental sampling. Hasil: Hasil penelitian diketahui bahwa nyeri pada ibu bersalin mengalami perubahan, hal ini terbukti berkurangnya rasa nyeri yang dialami responden pada saat pre tes kategori nyeri sedang menurun $24,4 \%$, dan responden berkategori nyeri berat menurun $14,3 \%$. Pijat oksitosin berpengaruh terhadap penurunan nyeri ibu bersalin dengan $\mathrm{P}$ sebesar 0,05. Sedangkan pada Kelompok ibu dengan pijat oksitosin maupun kelompok yang tidak dilakukan pijat oksitosin terhadap kemajuan persalinan tidak terdapat perbedaan, kedua kelompok sama-sama tidak mengalami percepatan dengan hasil $\mathrm{P}$ sebesar 0.099. Kesimpulan: Kesimpulan dari penelitian ini adalah pijat oksitotin berpengaruh menurunkan nyeri ibu bersalin.
\end{abstract}




\title{
Kata Kunci: Nyeri persalinan, pijat oksitosin
}

\begin{abstract}
Background: Childbirth is a physiological process that allows a series of major changes in a mother to be able to issue her student through a mother's birth path. Every pregnant mother is sure to crave a normal delivery and a minimum of pain. However, for a woman especially young mothers, the process of childbirth is often something very scary and synonymous with pain. Labor pain is a physiological process. If the pain is not addressed properly will cause other problems such as increased anxiety or worry about the process of childbirth so that the production of adrenal hormones increased and resulted in vasoconstriction that causes the flow Mother's blood to the fetus decreases. The fetus will experience hypoxia while the mother will experience prolonged labor and can also increase the cytolic and distolic pressures. Due to the fear of labor pains, not a few pregnant mothers who choose the Sectant area for the percopy, because they feel with the sectant Secarea of childbirth will be faster and far from pain. Maternity pain is the most feared by most pregnant mothers, there are many methods to reduce even relieving labor pains, one of which is using an oxytocin massage. Method: The method in this study is experimental quasi. Sampling is performed in accidental sampling. Results: The results of the study are known that the pain in maternity mothers has changed, it is evident that the pain suffered by respondents when pre test pain category was decreasing by $24.4 \%$, and the respondents in the category of severe pain decreased by $14.3 \%$. An ococysine massage affects the decrease in maternity pain with a $\mathrm{P}$ of 0.05 . While the mother group with the massage of oxytocin as well as a group that does not take massage oxytocin on the progress of childbirth there is no difference, both groups do not experience an acceleration with the result of 0099. Conclusion: The conclusion of this study is an influential occocytine massage lowers the pain of maternity mothers.
\end{abstract}

\section{Keywords: maternity pain, massage oxytocin}

\section{PENDAHULUAN}

Saat ini kesakitan dan kematian ibu dan anak masih menjadi masalah kesehatan. Di Indonesia angka kematian ibu (AKI) dan angka kematian bayi (AKB) masih tinggi yaitu angka kematian ibu 228/100.000 kelahiran hidup dan angka kematian bayi 34/100.000 kelahiran hidup. Jika dikaitkan dengan Millenium Development Goals (MDGs) 2015, yakni menurunkan angka kematian ibu (AKI) menjadi 102/100.000 kelahiran hidup dan angka kematian bayi (AKB) menjadi 23/100.000 kelahiran hidup yang harus dicapai. Adapun salah satu penyebabnya adalah persalinan lama. Persalinan lama merupakan komplikasi penyebab kematian ibu yang terbanyak nomor 5 di Indonesia. Persalinan lama rata-rata di dunia menyebabkan kematian ibu sebesar $8 \%$ dan di Indonesia sebesar 9\%.

Proses persalinan seringkali merupakan sesuatu yang sangat menakutkan dan identik dengan rasa nyeri. Nyeri persalinan merupakan proses yang fisiologis. Apabila nyeri tidak diatasi dengan baik akan menimbulkan masalah yang lain diantaranya meningkatnya kecemasan atau rasa khawatir akan proses persalinan sehingga produksi hormon adrenalin meningkat dan mengakibatkan vasokonstriksi yang menyebabkan aliran darah ibu ke janin menurun. Janin akan mengalami hipoksia sedangkan ibu akan mengalami persalinan lama dan dapat juga meningkatkan tekanan sitolik dan distolik.

Pengurangan rasa nyeri pada saat persalinan sebetulnya dapat dilakukan dengan metode bukan farmakologis yang cenderung lebih aman dan mudah. Salah satunya adalah 
dengan memberikan pijat oksitosin. Pijat oksitosin adalah sentuhan ringan atau pijatan tulang belakang mulai dari costa ke 5 - 6 sampai scapula yang dapat meninmbulkan efek relaksasi. Relaksasi yang dialami ibu merangsang otak untuk menurunkan kadar hormon adrenalin dan meningkatkan produksi oksitosin yang merupakan faktor timbulnya kontraksi uterus yang adekuat. Langkahlangkah dalam melakukan pijat oksitosin harus diperhatikan dengan baik agar pemijatan menghasilkan pengaruh yang optimal, salah satu langkah yang perlu diperhatikan adalah cara pemijatan pada setiap ibu dengan postur tubuh yang berbeda, seperti ibu yang gemuk harus dipijat dengan posisi telapak tangan mengepal sedangkan pada ibu dengan tubuh yang kurus atau normal bisa menggunakan jempol tangan kiri dan kanan atau punggung telunjuk kiri dan kanan. Selain itu, durasi pemijatan oksitosin pun perlu untuk diperhatikan, waktu yang baik untuk dilakukan pemijatan yaitu selama 3-5 menit.

Melihat begitu banyak manfaat yang didapat dengan melakukan pijat oksitosin saat persalinan oleh karena itu peneliti tertarik untuk mengambil penelitian dengan judul Pengaruh Pijat Oksitosin terhadap Nyeri Ibu Bersalin di Rumah Sakit Permata Bunda Purwodadi

\section{METODE PENELITIAN}

Penelitian ini merupakan penelitian analitik dilakukan dengan eksperimental menggunakan pre post test only control group design untuk mengetahui pengaruh perlakukan pada kelompok intervensi dengan cara membandingkan dengan kelompok control.

Populasi dalam penelitian ini adalah ibu yang melahirkan di Rumah Sakit Permata Bunda Purwodadi Bulan November 2018.

Sampel yang diteliti adalah ibu bersalin kala 1 fase aktif dimulai dari pembukaan 4 $\mathrm{cm}$ dengan teknik pengambilan sampel yaitu accidental sampling. Besar sampel 15 sampel per kelompok yaitu 15 responden yang diberikan pijat oksitosin dan 15 sampel yang tidak diberikan pijat oksitosin. Penelitian ini menggunakan data primer yang diperoleh dengan cara mengobservasi ibu bersalin kala 1 fase aktif dimulai dari pembukaan $4 \mathrm{~cm}$ dengan mengobservasi patograf di Rumah Sakit Permata Bunda Purwodadi. Setelah semua data terkumpul, maka peneliti melakukan pengolahan data melalui beberapa tahap yaitu memeriksa ketepatan dan kelengkapan data. Data yang telah terkumpul dikoreksi ketepatan dan kelengkapannya, kemudian dimasukkan kedalam program komputer. Data disajikan dalam bentuk distribusi frekuensi. Analasis data yang digunakan pada penelitian ini adalah bivariat. Analisis bivariate dalam penelitian ini dilakukan untuk melihat pengaruh variabel Pijat oksitosin dengan Nyeri persalinan. Dengan menggunakan uji statistic yaitu chi square.

\section{HASIL PENELITIAN}

Berdasarkan tabel 1 terlihat, terdapat perbedaan tingkat nyeri sebelum dilakukan perlakuan antara masing-masing kelompok perlakuan

Tabel 1. Perbedaan Nyeri Ibu Bersalin sebelum dan sesudah diberikan Pijat oksitosin dan Tidak Pijat Oksitosin di Rumah Sakit Permata Bunda Purwodadi

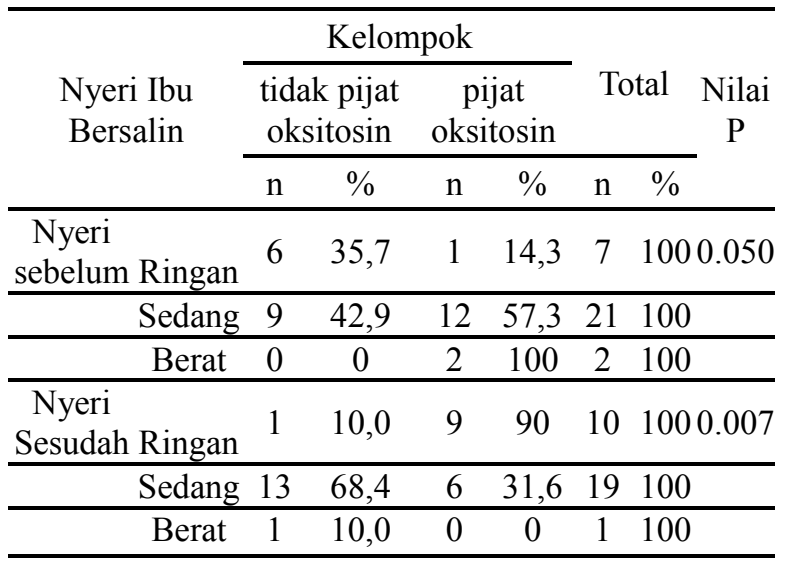

Berdasarkan nyeri sebelum diberikan perlakuan 12 orang dari 21 orang yang masuk kategori nyeri sedang, sedangkan berdasarkan 
kategori nyeri sesudah diberikan perlakuan dari 19 orang yang memiliki nyeri sedang, 13 orang diantaranya tidak melakukan Pijat Oksitosin dan 6 orang diantaranya melakukan Pijat Oksitosin. Berdasarkan hasil pengolahan statistic dengan uji chisquare diperoleh nilai $\mathrm{P}$ sebesar 0,007. Karena nilai $\mathrm{P}(0,007)<0,05$ maka bermakna Artinya terdapat perbedaan tingkat nyeri sesudah dilakukan perlakuan antara masing-masing kelompok perlakuan

\section{PEMBAHASAN}

Berdasarkan Tabel 1 dapat dilihat bahwa kategori nyeri pada kelompok pijat oksitosin paling tinggi adalah nyeri sedang yaitu 57,1 $\%$, sedangkan pada kelompok tidak pijat oksitosin terbanyak adalah nyeri sedang yaitu $42,9 \%$. Tabel 4.1 juga menunjukkan rata-rata nyeri setelah perlakuan bahwa kelompok pijat oksitosin dengan kategori nyeri terbanyak adalah nyeri ringan yaitu $90,0 \%$. Sedangkan kelompok tidak pijat oksitosin kategori nyeri terbanyak adalah nyeri sedang yaitu $68,4 \%$.

Berdasarkan Tabel 1 dapat dilihat bahwa nyeri kelompok pijat oksitosin mengalami peurunan, hal ini terbukti menurun nya jumlah responden yang berada dalam kategori nyeri sedang, dari $57,1 \%$ saat pre tes menjadi $36,7 \%$ saat post tes, dan responden yang berada dalam kategori nyeri berat dari 14,3\% saat pre tes menjadi $0 \%$ saat post tes. Sehingga dapat disimpulkan bahwa pijat oksitosin dapat menurunkan nyeri.

Berbeda dengan kelompok tidak pijat oksitosin yang mengalami kenaikan, hal ini terbukti meningkatnya jumlah responden yang berada dalam kategori nyeri sedang, dari $42,9 \%$ saat pre tes menjadi $68,4 \%$ saat post tes, dan responden yang berada dalam kategori nyeri berat dari $0 \%$ orang menjadi $5 \%$ saat post tes.

Nyeri pada ibu bersalin disebabkan oleh pasokan oksigen ke otot rahim berkurang, karena adanya kontraksi yang singkat menyebabkan nyeri menjadi lebih tinggi sehingga pasokan oksigen ke otot rahim belum sepenuhnya pulih. Pada kala I persalinan, nyeri disebabkan oleh adanya kontraksi uterus yang mengakibatkan dilatasi dan penipisan

Pada ibu bersalin yang diberikan pijat oksitosin mengatakan bahwa merasa lebih tenang, lebih nyaman dalam menghadapi persalinan. Pemijatan yang diberikan memberi manfaat pada ibu bersalin yaitu melancarkan peredaran darah dan meregangkan daerah otot-otot sehingga nyeri yang dialami selama proses persalinan juga semakin berkurang. Tindakan pijat oksitosin pada saat pasien merasakan nyeri akibat persalinan dapat membantu bidan dalam memberikan asuhan kebidanan, karena pemberian pijat oksitosin pada ibu bersalin normal kala I fase aktif persalinan ini dapat meminimalkan efek samping yang muncul dan dengan biaya yang murah.

Hasil post tes pada kelompok pijat oksitosin menunjukkan penurunan tingkat nyeri pada ibu bersalin setelah dilakukan pijat oksitosin. Penurunan nyeri ini dikarenakan teknik ini mempunyai cara kerja merangsang tubuh melepaskan senyawa endorphin.

Dalam penelitian ini, pijat oksitosin sangat bermanfaat untuk ibu bersalin karena dapat menurunkan nyeri saat bersalin. Ketika nyeri dapat ditangani, ibu akan merasa rileks dan nyaman sehingga bisa mengikuti proses persalinan dengan tenang. Ketika kondisi ibu saat persalinan dalam kondisi tenang persalinan akan berjalan dengan normal. Jika ibu bersalin dalam keadaan stress system syaraf simpatis berfungsi mempertahankan aktifitas jantung. Hambatan pada syaraf simpatis akan menurunkan frekuensi dan sedikit mengurangi variabilitas denyut jantung janin. Jika ibu tidak bisa rileks dalam proses persalinan dapat menimbulkan kegelisahan dan respon endokrin, dan hal ini dapat menyebabkan retensi natrium, ekskresi kalium dan penurunan glukosa. Kondisi ini dapat menyebabkan sekresi epinephrine yang dapat menyebabkan penghambatan aktifitas miometrium sehingga menyebabkan kontraki uterus terganggu. Jika dalam persalinan kontraksi uterus terganggu, persalinan tidak akan berjalan dengan semestinya.

Hasil penelitian ini memperlihatkan 
bahwa pijat oksitosin diperlukan bagi ibu bersalin sejak kala I. Kemampuan mentolerir stress persalinan tergantung pada persepsi individu terhadap peristiwa persalinan yang dihadapi. Pijat oksitosin merupakan suatu bentuk kasih sayang yang bisa bidan atau keluarga berikan terhadap ibu yang akan bersalin. Sikap tersebut memiliki keuntungan: Ibu merasa aman dan mampu mengontrol dirinya. Ibu yang diberikan sentuhan mengalami kehangatan dan persahabatan selama persalinan lebih dapat menangani bayinya.

Metode pijat oksitosin saat persalinan membantu meningkatkan pelepasan zat oksitosin, sebuah hormon yang memfasilitasi persalinan, mengendalikan rasa nyeri yang menetap, mengendalikan perasaan stress, mengurangi atau meringankan rasa sakit pada ibu yang akan melahirkan, dapat meningkatkan kondisi rileks dalam tubuh dengan memicu perasaan nyaman melalui permukaan kulit, mengurangi risiko terjadinya komplikasi dalam persalinan dan terjadinya perdarahan. Kondisi yang tenang membuat keseimbagan hormon dalam tubuh, dan pijat ini juga sangat membantu menguatkan ikatan antara istri dan suami atau penolong persalinan yang memijat ibu.

Menurut penelitian Morhen tahun 2008 membuktikan bahwa pijat oksitosin dapat meningkatkan kepercayaan dan kenyamanan sehingga meskipun kontraksi bertambah, rasa nyeri pun berkurang bahkan tidak dirasakan. Pijat oksitosin juga dapat meningkatkan oksitosin, karena oksitosin sangat dibutuhkan dalam proses persalinan

Menurut penelitian Aryani tahun 2015, menyatakan bahwa pijatan yang diberikan secara sering saat ibu menghadapi persalinan dapat menekan produksi mediator nyeri, ketika nyeri berkurang ibu pun dapat tenang dan bisa beradaptasi pada keadaan persalinan nya sehingga persalinan berjalan dengan baik yaitu patograf dalam batas normal.

Melihat hasil penelitian yang menunjukkan adanya penurunan nyeri yang signifikan setelah dilakukan pijat oksitosin, maka pijat oksitosin ini dapat dijadikan pilihan karena tidak ada efek samping bagi ibu ataupun janinnya, dibandingkan dengan beberapa metode persalinan yang biasa ibu pilih untuk mengurangi nyeri persalinan, seperti seksio sesarea yang memiliki efek samping yang dapat membahayakan ibu dan juga janinnya

\section{KESIMPULAN}

Berdasarkan penelitian yang telah dilakukan, metode pijat oksitotin dapat berpengaruh menurunkan nyeri pada ibu bersalin.

\section{SARAN}

Kepada peneliti selanjutnya diharapkan agar berupaya lebih mengembangkan dan memperdalam bahasan tentang Pengaruh Pijat Oksitosin terhadap Nyeri Persalinan Pada Ibu Bersalin dengan menggunakan desain penelitian yang berbeda.

\section{DAFTAR PUSTAKA}

Aprillia, Yessie. 2010. Hipnostetri : Rileks, Nyaman, dan Aman Saat Hamil dan Melahirkan. Jakarta: Gagas Media

Aprillia. 2008. Workbook pelatihan hypnobirthing, Pro V linic, Jakarta

Aryani, Y., \& Evareny, L. Pengaruh Masase pada Punggung Terhadap Intensitas Nyeri Kala I Fase Laten

Astuti, A. P dan Masruroh. 2013. "Perbedaan Lama Kala 1 Fase Aktif pada Ibu Bersalin yang Dilakukan dan yang Tidak Dilakukan Pijat Endorphin di RB Maargo Waluyo Surakarta". Jurnal Kebidanan. Vol. V, No. 01: 30-36

Departemen Kesehatan Republik Indonesia. Profil kesehatan Indonesia tahun 2010. Jakarta: Depkes RI

Danuatja, B. 2010. Persalinan Normal Tanpa Rasa Sakit. Jakarta : Pupa Swara

Donaldson, Z. R., \& Young, L. J. 2008. Oxytocin, vasopressin, and the neurogenetics of sociality. Science, 322 (5903), 900-904 
E Kusyati, LP Astuti. 2012. Efektivitas Teknik Relaksasi Nafas Dalam Terhadap Tingkat Nyeri Persalinan Kala I. Jurnal Kebidanan, Vol. IV, No. 02, Hal 93-100

Fuchs, A. R., Fuchs, F., Husslein, P., Soloff, M. S., \& Fernstrom, M. J. (1982). Oxytocin receptors and human parturition: a dual role for oxytocin in the initiation of labor. Science, 215(4538), 1396-1398.

Kuswandi, Lanny. 2007. Terapi hypnobirthing: melahirkan tanpa rasa sakit persalinan. Jakarta

Mander, Rosemary. 2004. Nyeri Persalinan. Jakarta : EGC

Morhenn, V. B., Park, J. W., Piper, E., \& Zak, P. J. 2008.Monetary sacrifice among strangers is mediated by endogenous oxytocin release after physical contact. Evolution and Human Behavior, 29 (6), 375-383

Manurung S., at all. 2013. Pengaruh Pemberian Kompres Hangat Terhadapa Perubahan Skala Nyeri Persalinan Pada Klien Primigravida. Jurnal Health Quality Vol.4 No.1 Hal. 1-76

Notoadmojo, S. 2012. Metodologi Penelitian Kesehatan. Jakarta : Rineka Cipta

Rini, Susilo. Kumala, Feti, SST.,M.Kes. 2016. Panduan asuhan nifas dan Evidence based practice. Yogyakarata: Deepublish

Reni Ilmiasih, Skep Ners. 2004. Pengaruh teknik hypnobirthing terhadap tingkat kecemasan ibu hamil pada masa persiapan meghadapi persalinan, Malang : Fakultas Ilmu Kesehatan Jurusan Keperawatan Universitas Muhammadiyah Malang

Yuliatun, L. 2008. Penanganan Nyeri Persalinan dengan Metode Nonfarmakologis. Malang 